\title{
Application of beet sugar byproducts improves sugar beet biofortification in saline soils and reduces sugar losses in beet sugar processing
}

Fahad Alotaibi

King Abdulaziz City for Science And Technology

\section{Atif A. Bamagoos}

King Abdulaziz University Faculty of Sciences

Fekry M. Ismaeil

Delta Sugar Company, Egypt

Wenying Zhang

Yangtze University

Salah Fatouh Abou-Elwafa ( $\sim$ elwafa75@aun.edu.eg )

Assiut University Faculty of Agriculture https://orcid.org/0000-0002-9018-598X

\section{Research Article}

Keywords: Beta vulgaris, Salinity, Filter cake, Molasses, Sugar loss

Posted Date: February 5th, 2021

DOI: https://doi.org/10.21203/rs.3.rs-204834/v1

License: @ (i) This work is licensed under a Creative Commons Attribution 4.0 International License. Read Full License

Version of Record: A version of this preprint was published at Environmental Science and Pollution Research on February 15th, 2021. See the published version at https://doi.org/10.1007/s11356-021-12935-5. 


\section{Abstract}

Improving the chemical and physical properties of saline soils is crucial for the sustainable production of sugar beet and efficient processing of beet sugar. Here, the impacts of the application of treated filter cake on sugar beet biofortification under saline soil and sugar losses into molasses during beet sugar processing were evaluated for the first time. The application of treated filter cake significantly reduced $\mathrm{K} \%, \mathrm{Na} \%$ and a-amino-N while enhanced sucrose content and quality index of beet root juice. Consequently, sugar loss percentage, sugar loss yield and relative sugar loss yield were reduced, whereas recoverable sugar yield was enhanced. Linear regression analysis revealed that quality index and sugar loss yield were increased, whereas sugar loss percentage and relative sugar loss yield were reduced in response to the reduction of soil $\mathrm{Na}+$ content accompanied with increasing $\mathrm{Ca} 2+$ content in the soil increased. The results provide treated filter cake as a promising amendment for saline soils remediation for improving biofortification of sugar beet and reducing sugar losses during beet sugar processing.

\section{Introduction}

Cultivation of sugar beet (Beta vulgaris, L.), one of the most salt-tolerant crops (Kaffka and Hembree 2004, Kaffka, et al. 2005, Lv, et al. 2019), in the tropical and subtropical countries is growing rapidly as an important component of the sugar industry. It is considered a promising source to supplement or replace cane sugar production in these countries because of its ability to produce higher sugar yields in a short growing season in the newly reclaimed soils dominating these countries which are mostly characterized as saline or salt-affected soils (Abo-Elwafa et al. 2013, Abo-Elwafa et al. 2006, Abou-Elwafa et al. 2020, Balakrishnan \&Selvakumar 2009).

Increasing soil salinity level $\left(\mathrm{EC}>6 \mathrm{dSm}^{-1}\right)$ promotes ion toxicity, nutritional imbalances, oxidative stress, decreasing the soil available water, cell division and changes in metabolic processes such as photosynthesis and disrupt plant membranes (Ding et al. 2020, Hasanuzzaman et al. 2014). In addition, the quality of sugar beet root juice has been also found to be adversely affected under high levels of salt in the soil (Dadkhah 2008, Wu et al. 2003). Increasing the levels of salt concentration in the soil significantly increases the concentration of the total soluble solids (TSS) in beet root juice. Furthermore, the uptake of more sodium by sugar beet roots increases the level of impurities in the beet root juice, and consequently, its quality is decreased (Draycott \&Christenson 2003). Therefore, it is of great importance for promoting sugar beet cultivation and production of sugar beet in saline soils dominating subtropical and tropical regions to improve the physical and chemical properties of such soils. Several methods have been implemented for powerful, low cost and successful remediation of soil salinity including organic, calcium chemical and sulfur-containing compounds (Cha-um \&Kirdmanee 2011, Ding et al. 2020, Jesus et al. 2015). The application of gypsum, a sulfate mineral composed of calcium sulfate dehydrate, improves the productivity and biofortification of fodder beet in saline soils and enhance the physical and chemical characteristics of the soil (Ahmed et al. 2015). Foliar application of humic acid significantly enhances sucrose content, extractable sugar, and root and sugar yields, and reduces sugar loss to molasses in sugar beet (El-Hassanin et al. 2016). Besides, the application of humic substances improves the physical and chemical characteristics of the soil including aeration, aggregation, water holding capacity, permeability and micronutrient availability (Tan 2003) The application of molasses, the residual syrup from sugar processing, alleviates the negative impacts of soil salinity (El-Tokhy et al. 2019).

Large amounts of sugar beet industrial byproducts (170,000 tons of filter cake annually) are produced from beet sugar processing in Egypt causing tremendous environmental pollution. Filter cake, a byproduct of using the ground limestone in beet root juice clarification, is a valuable byproduct that is rich in calcium and organic matter and has relatively high cation-exchange capacity (CEC) values (Ippolito et al. 2013). Filter cake that is considered a rich source of organic matter and phosphorus with a large moisture content has been extensively implemented to completely or partially substitute the application of mineral fertilizers in crop plants including sugar beet in different countries, including India, Brazil, Cuba, Australia, Pakistan, South Africa, Taiwan and Argentina (Basha 2011, Ossom \&Dlamini 2012, Ossom \&Rhykerd 2007, Ossom 2010). However, the high pH value of the filter cake has prevented its direct application as a fertilizer or soil amendment to the Egyptian soils which undergone high pH levels (7.9-8.2; (Messiha et al. 2007)). Therefore, modifying the chemical characteristics of the filter cake is a prerequisite for its utilization and application as a soil amendment or a fertilizer in saline soils with high pH levels. 
The current study hypothesizes that because of its high calcium content, treated filter cake could effectively enhance sugar beet biofortification and reduces sugar losses into molasses during beet sugar processing. Therefore, the current study was carried out to; i) convert the filter cake from an environmentally harmful byproduct to a useful material could be successfully applied for remediation of saline soils, and ii) evaluate the impact treated filter cake applied as a soil amendment on the quality of beet root juice and sugar losses during the processing of sugar beet under the saline soil condition.

\section{Material And Methods}

\section{Plant material and field experiment}

A field experiment was carried out at the Delta Sugar Company Research Farm, El-Hamool, Kafr El-Sheikh, Egypt (31 ${ }^{\circ} 06^{\prime} \mathrm{N}, 30^{\circ} 56^{\prime}$ E, $17 \mathrm{~m}$ asl) during the $2017 / 2018$ and 2018/2019 growing seasons. Two commercial sugar beet varieties, i.e., Top and Bleno were implemented in the first and second growing seasons, respectively. Sowing was performed on October 22 and harvest was performed on April 15 in both growing seasons. Seeds were sown by hand at $15-20 \mathrm{~cm}$ distance in a $15 \mathrm{~m}^{2}$ plot consists of five rows of $5 \mathrm{~m}$ in length, with a distance of $60 \mathrm{~cm}$ between rows. $\mathrm{N}, \mathrm{P}$ and $\mathrm{K}$ fertilizers and all other agronomical practices were performed as locally recommended for sugar beet cultivation and production. Briefly, super phosphate $\left(15.5 \% \mathrm{P}_{2} \mathrm{O}_{5}\right)$ at the rate of $474 \mathrm{~kg} \mathrm{ha}^{-1}$ was added during soil preparation. Nitrogen was added in the form of urea $(46.5 \% \mathrm{~N})$ at the rate of $214 \mathrm{~kg} \mathrm{ha}^{-1}$ in two equal dosages, i.e., after thinning with second irrigation, and with the third irrigation. Potassium sulfate $\left(50 \% \mathrm{~K}_{2} \mathrm{O}\right)$ was applied with the first irrigation at the rate of $119 \mathrm{~kg} \mathrm{ha}^{-1}$. Furrow irrigation was followed and irrigation quotas are given in Suppl. Table 1. All plots received the same treatments in both growing seasons.

\section{Characterization Of Applied Soil Amendments}

Five soil amendments were used in the current study. i) phosphogypsum (PG) which is produced as a byproduct from phosphate rock processing in phosphate fertilizers plants, ii) desaline (DS) which is a commercial product used for desalination contains $5 \%$ N, 5\% P, 5\% K, 5\% Ca, 2.5\% Mg, 5.5\% humic acid, 0.5\% salicylic acid, 20\% Citric acid and 5\% polysaccharides, iii) treated filter cake (TFC) which is a byproduct resulted from using the ground limestone in beet juice clarification treated with some chemicals (particularly lime-carbon dioxide, calcium hydroxide sulfuric acid and calcium sulfate), iv) molasses which is a residual syrup from sugar beet or sugarcane processing, and v) humic acid. To convert the filter cake from a harmful to a useful material that could be used as a soil amendment, a mixture of 1.5:1 of sulfuric and phosphoric acids was added to the filter cake produced from Delta Sugar Company at the rate of $180 \mathrm{~cm}^{3}$ of sulfuric acid and $120 \mathrm{~cm}^{3}$ of phosphoric acid $\mathrm{kg}^{-1}$ of the filter cake. All five types of soil amendments were applied to the soil surface before planting. Chemical characterization of raw filter cake (RFC), treated filter cake (TFC) and molasses are shown in Suppl. Tables. 1, 2 and 3.

\section{Phenotypic Evaluation}

At harvest, a representative root sample from each plot was used for juice quality analysis by estimating sucrose\%, potassium $(\mathrm{K}) \%$, sodium ( $\mathrm{Na}) \%$ and a-amino-N\% in the root juice using the venma, Automation BV AnalyzerlIG-16-12-99, 9716JP/ Groningen/Holland according to the procedure used by the Delta Sugar Company, as described by (Le-Docte 1927) and (Abejehu 2015). The results were calculated as mmol $100 \mathrm{~g}^{-1}$ beet. Quality index, Sucrose losses\%, and sugar loss yield were calculated using the following equations according to (Reinefield et al. 1974):

Sucrose losses $(\mathrm{SL}) \%=0.14(K+N a)+0.25(\alpha-$ amino $N)+0.5$

Sugar loss yield $(S L Y)=$ Root yield $\times$ sugar losses $\%$

The relative loss in sugar yield was calculated as a percentage of the sugar loss yield to the totals sugar yield including recoverable sugar yield and sugar loss yield as follow:

$=\frac{\text { Sugar loss yield }(S L Y)}{\text { Sugar loss yield }(S L Y)+\text { Recoverable sugar yield }} \times 100$

Page $3 / 16$ 


\section{Soil analysis}

Composite representative samples of the experimental soil were collected from the surface layer $(0-30 \mathrm{~cm})$ before sowing to analyze its physical and chemical properties. After harvest, the soil was sampled from each plot. Soil samples were air-dried, ground and sieved in a $2 \mathrm{~mm}$ sieve. The soil pH was estimated in a suspension of 1:2.5 of soil to deionized water using a glass electrode (Jackson 1973). The soil electrical conductivity (EC) was measured in an extract of 1:2.5 of soil to water using the EC meter (Hesse 1998). The available soil nitrogen was estimated using micro-kjeldahl procedure after nitrogen extraction using $2 \mathrm{M}$ potassium chloride (Burt 2004). The spectrophotometer set at a wavelength of $550 \mathrm{~nm}$ was employed to measure the available soil phosphorus after extraction using $0.5 \mathrm{M}$ sodium bicarbonate solution at pH 8.5 (Olsen 1954). The extractable soil potassium was measured using flame photometry after extraction using ammonium acetate procedure at pH 7.0 (Jackson 1973). The soil organic matter (OM) was estimated using the Walkley-Black procedure (Jackson 1973). The main physical and chemical soil characteristics are presented in Suppl. Table 5.

\section{Experimental design and statistical analysis}

The randomized complete block design (RCBD) with four replicates was employed to design the field experiment. Seven soil amendment treatments, i.e., control treatment (without amendments), $62.5 \mathrm{~L} \mathrm{ha}^{-1}$ of molasses and $125 \mathrm{~L} \mathrm{ha}^{-1}$ of molasses, 2.5 ton $\mathrm{ha}^{-1}$ of TFC, 5 ton ha-1 of TFC, 2.5 ton ha-1 of PG, $10 \mathrm{~L} \mathrm{ha}^{-1}$ of DS, and $10 \mathrm{~L} \mathrm{ha}^{-1}$ of humic acid were used. The Proc Mixed of SAS 130 package version 9.2 was employed for analysis of variance (ANOVA) and Fisher's least significant difference (LSD) of treatments exhibiting significant differences. The SigmaPlot 14 Software (Systat Software, San Jose, CA, USA) was employed to conduct the linear regression.

\section{Experimental Design And Statistical Analysis}

The randomized complete block design (RCBD) with four replicates was employed to design the field experiment. Seven soil amendment treatments, i.e., control treatment (without amendments), $62.5 \mathrm{~L} \mathrm{ha}^{-1}$ of molasses and $125 \mathrm{~L} \mathrm{ha}^{-1}$ of molasses, 2.5 ton ha ${ }^{-1}$ of TFC, 5 ton ha ${ }^{-1}$ of TFC, 2.5 ton ha-1 of PG, $10 \mathrm{~L} \mathrm{ha}^{-1}$ of DS, and $10 \mathrm{~L} \mathrm{ha}^{-1}$ of humic acid were used. The Proc Mixed of SAS 130 package version 9.2 was employed for analysis of variance (ANOVA) and Fisher's least significant difference (LSD) of treatments exhibiting significant differences. The SigmaPlot 14 Software (Systat Software, San Jose, CA, USA) was employed to conduct the linear regression.

\section{Results}

\section{Beet sugar byproducts improve beet biofortification and juice quality}

Sucrose content, $\mathrm{K} \%, \mathrm{Na} \%$ and $\mathrm{a}$-amino $\mathrm{N} \%$ are the main parameters that influence sugar beet juice quality and thereby the recoverable sugar and sugar losses. Soil amendments significantly affected sucrose content, $\mathrm{K} \%, \mathrm{Na} \%$ and a-amino $\mathrm{N} \%$ in both growing seasons (Table 1). The highest sucrose content (19.37\%, and $19.47 \%$ ) produced from the control treatment in the first and second growing seasons, respectively (Table 1). The application of soil amendments, treated filter cake in particular, significantly reduced $\mathrm{K} \%, \mathrm{Na} \%$ and $\mathrm{a}-\mathrm{amino}-\mathrm{N}$ in beet root juice in both growing seasons. The lowest values of $\mathrm{K} \%, \mathrm{Na} \%$ and aamino $\mathrm{N} \%$ were produced from the application of treated filter cake at the rate of 2.5 ton $\mathrm{ha}^{-1}$ in both growing seasons (Table 1). Consequently, the application of beet sugar byproducts significantly enhanced the quality index of beet root juice (Qz\%). The highest quality index values ( 77.44 and $86.66 \%$, in the first and second growing seasons, respectively) were produced from the application of 2.5 ton $\mathrm{ha}^{-1}$ of treated filter cake (Table 1 ). 
Table 1

Effect of soil amendments application on sucrose $\%, \mathrm{Na} \%, \mathrm{~K} \%$, a-amino $\mathrm{N}$ and quality index (Qz\%) of sugar beet in the $2017 / 2018$ and 2018/2019 growing seasons.

\begin{tabular}{|c|c|c|c|c|c|c|c|c|c|c|}
\hline \multirow[t]{2}{*}{ Treatment } & \multicolumn{5}{|c|}{$2017 / 2018$} & \multicolumn{5}{|c|}{$2018 / 2019$} \\
\hline & $\begin{array}{l}\text { Sucrose } \\
(\%)\end{array}$ & $\mathrm{K}(\%)$ & $\begin{array}{l}\mathrm{Na} \\
(\%)\end{array}$ & $\begin{array}{l}\text { a-amino } \\
\mathbf{N}(\%)\end{array}$ & Qz\% & $\begin{array}{l}\text { Sucrose } \\
(\%)\end{array}$ & $\mathrm{K}(\%)$ & $\begin{array}{l}\mathrm{Na} \\
(\%)\end{array}$ & $\begin{array}{l}\text { a-amino } \\
\mathbf{N}(\%)\end{array}$ & Qz\% \\
\hline Control & $\begin{array}{l}19.37 \pm \\
0.22\end{array}$ & $\begin{array}{l}8.50 \pm \\
0.32\end{array}$ & $\begin{array}{l}4.59 \pm \\
0.08\end{array}$ & $\begin{array}{l}2.75 \pm \\
0.07\end{array}$ & $\begin{array}{l}74.71 \\
\pm 1.97\end{array}$ & $\begin{array}{l}19.47 \pm \\
0.32\end{array}$ & $\begin{array}{l}5.18 \\
\pm 0.34\end{array}$ & $\begin{array}{l}2.11 \pm \\
0.10\end{array}$ & $\begin{array}{l}1.49 \pm \\
0.09\end{array}$ & $\begin{array}{l}84.90 \\
\pm 4.25\end{array}$ \\
\hline $\begin{array}{l}\text { Molasses }(62.5 \\
\left.\mathrm{L} \mathrm{ha}^{-1}\right)\end{array}$ & $\begin{array}{l}19.09 \pm \\
0.19\end{array}$ & $\begin{array}{l}8.17 \pm \\
0.21\end{array}$ & $\begin{array}{l}4.18 \pm \\
0.11\end{array}$ & $\begin{array}{l}2.30 \pm \\
0.09\end{array}$ & $\begin{array}{l}76.07 \\
\pm 2.37\end{array}$ & $\begin{array}{l}19.22 \pm \\
0.29\end{array}$ & $\begin{array}{l}5.02 \\
\pm 0.44\end{array}$ & $\begin{array}{l}1.93 \pm \\
0.12\end{array}$ & $\begin{array}{l}1.41 \pm \\
0.12\end{array}$ & $\begin{array}{l}85.28 \\
\pm 4.11\end{array}$ \\
\hline $\begin{array}{l}\text { Molasses }(125 \mathrm{~L} \\
\left.\mathrm{ha}^{-1}\right)\end{array}$ & $\begin{array}{l}19.14 \pm \\
0.25\end{array}$ & $\begin{array}{l}7.87 \pm \\
0.19\end{array}$ & $\begin{array}{l}4.02 \pm \\
0.06\end{array}$ & $\begin{array}{l}2.09 \pm \\
0.11\end{array}$ & $\begin{array}{l}76.32 \\
\pm 3.45\end{array}$ & $\begin{array}{l}19.09 \pm \\
0.20\end{array}$ & $\begin{array}{l}5.14 \\
\pm 0.29\end{array}$ & $\begin{array}{l}1.77 \pm \\
0.09\end{array}$ & $\begin{array}{l}1.43 \pm \\
0.11\end{array}$ & $\begin{array}{l}85.22 \\
\pm 2.98\end{array}$ \\
\hline $\operatorname{TFC}\left(2.5 \mathrm{t} \mathrm{ha}^{-1}\right)$ & $\begin{array}{l}18.36 \pm \\
0.26\end{array}$ & $\begin{array}{l}7.41 \pm \\
0.27\end{array}$ & $\begin{array}{l}3.52 \pm \\
0.12\end{array}$ & $\begin{array}{l}1.87 \pm \\
0.05\end{array}$ & $\begin{array}{l}77.44 \\
\pm 1.78\end{array}$ & $\begin{array}{l}18.92 \pm \\
0.41\end{array}$ & $\begin{array}{l}5.05 \\
\pm 0.42\end{array}$ & $\begin{array}{l}1.94 \pm \\
0.11\end{array}$ & $\begin{array}{l}1.40 \pm \\
0.08\end{array}$ & $\begin{array}{l}85.86 \\
\pm 3.75\end{array}$ \\
\hline $\operatorname{TFC}\left(5 \mathrm{tha}^{-1}\right)$ & $\begin{array}{l}18.62 \pm \\
0.20\end{array}$ & $\begin{array}{l}7.55 \pm \\
0.26\end{array}$ & $\begin{array}{l}3.51 \pm \\
0.13\end{array}$ & $\begin{array}{l}2.13 \pm \\
0.10\end{array}$ & $\begin{array}{l}75.62 \\
\pm 2.67\end{array}$ & $\begin{array}{l}19.19 \pm \\
0.24\end{array}$ & $\begin{array}{l}5.12 \\
\pm 0.39\end{array}$ & $\begin{array}{l}1.97 \pm \\
0.11\end{array}$ & $\begin{array}{l}1.34 \pm \\
0.14\end{array}$ & $\begin{array}{l}85.03 \\
\pm 3.94\end{array}$ \\
\hline Phosphogypsum & $\begin{array}{l}18.19 \pm \\
0.11\end{array}$ & $\begin{array}{l}7.86 \pm \\
0.12\end{array}$ & $\begin{array}{l}4.08 \pm \\
0.20\end{array}$ & $\begin{array}{l}2.32 \pm \\
0.14\end{array}$ & $\begin{array}{l}74.80 \\
\pm 3.39\end{array}$ & $\begin{array}{l}19.26 \pm \\
0.33\end{array}$ & $\begin{array}{l}5.23 \\
\pm 0.22\end{array}$ & $\begin{array}{l}1.99 \pm \\
0.14\end{array}$ & $\begin{array}{l}1.44 \pm \\
0.19\end{array}$ & $\begin{array}{l}85.12 \\
\pm 3.42\end{array}$ \\
\hline Desaline & $\begin{array}{l}19.46 \pm \\
0.29\end{array}$ & $\begin{array}{l}7.83 \pm \\
0.17\end{array}$ & $\begin{array}{l}4.22 \pm \\
0.11\end{array}$ & $\begin{array}{l}2.00 \pm \\
0.19\end{array}$ & $\begin{array}{l}75.78 \\
\pm 2.85\end{array}$ & $\begin{array}{l}19.11 \pm \\
0.28\end{array}$ & $\begin{array}{l}5.29 \\
\pm 0.31\end{array}$ & $\begin{array}{l}2.10 \pm \\
0.18\end{array}$ & $\begin{array}{l}1.62 \pm \\
0.13\end{array}$ & $\begin{array}{l}84.67 \\
\pm 5.12\end{array}$ \\
\hline Humic acid & $\begin{array}{l}18.61 \pm \\
0.24\end{array}$ & $\begin{array}{l}7.65 \pm \\
0.21\end{array}$ & $\begin{array}{l}3.69 \pm \\
0.18\end{array}$ & $\begin{array}{l}2.14 \pm \\
0.08\end{array}$ & $\begin{array}{l}77.10 \\
\pm 3.58\end{array}$ & $\begin{array}{l}19.24 \pm \\
0.27\end{array}$ & $\begin{array}{l}5.18 \\
\pm 0.25\end{array}$ & $\begin{array}{l}2.02 \pm \\
0.14\end{array}$ & $\begin{array}{l}1.56 \pm \\
0.21\end{array}$ & $\begin{array}{l}85.10 \\
\pm 3.86\end{array}$ \\
\hline Significance & ** & ** & $\star *$ & ** & ** & ** & ** & * & * & ** \\
\hline $\operatorname{LSD}_{0.05}$ & 0.30 & 0.11 & 0.14 & 0.14 & 0.46 & 0.18 & 0.10 & 0.11 & 0.11 & 0.45 \\
\hline
\end{tabular}

\section{The application of treated filter cake and molasses reduces sugar loss in beet sugar processing}

The application of soil amendments significantly reduced sugar loss percentage, sugar loss yield and relative sugar loss yield (Fig. 1). The lowest values of sugar loss percentage resulted from the application of treated filter cake either at the rates of 2.5 or 5 ton ha ${ }^{-1}$ in both growing seasons (Table 2). The lowest sugar loss yield (1.28 ton ha ${ }^{-1}$ ) resulted from the application of phosphogypsum in the first growing season, while in the second growing season the application of either $62.5 \mathrm{~L} \mathrm{ha}^{-1}$ of molasses or humic acid resulted in the lowest sugar yield (1.16 and 1.15 ton ha ${ }^{-1}$, respectively). The application of 2.5 ton ha ${ }^{-1}$ of treated filter cake resulted in the lowest relative sugar loss yield (14.06\%) in the first growing seasons. Meanwhile, the lowest values in the second growing season resulted from the application of either 5 ton ha-1 of treated filter cake or $125 \mathrm{~L} \mathrm{ha}^{-1}$ of molasses (Table 2). 
Table 2

Effect of soil amendments application on sugar loss (SL\%), sugar loss yield (SLY) and relative sugar loss yield (RSLY) of sugar beet in the $2017 / 2018$ and $2018 / 2019$ growing seasons.

\begin{tabular}{|c|c|c|c|c|c|c|}
\hline \multirow[t]{2}{*}{ Treatment } & \multicolumn{3}{|l|}{$2017 / 2018$} & \multicolumn{3}{|l|}{$2018 / 2019$} \\
\hline & SL (\%) & $\operatorname{SLY}\left(\mathrm{tha}^{-1}\right)$ & RSLY (\%) & SL (\%) & $\operatorname{SLY}\left(\mathrm{tha}^{-1}\right)$ & RSLY (\%) \\
\hline Control & $2.71 \pm 0.18$ & $1.53 \pm 0.09$ & $17.56 \pm 0.96$ & $1.98 \pm 0.15$ & $1.29 \pm 0.14$ & $11.32 \pm 1.33$ \\
\hline Molasses (62.5 L ha-1) & $2.60 \pm 0.13$ & $1.59 \pm 0.12$ & $16.23 \pm 0.75$ & $1.83 \pm 0.12$ & $1.17 \pm 0.11$ & $10.21 \pm 1.06$ \\
\hline Molasses (125 L ha-1) & $2.39 \pm 0.21$ & $1.54 \pm 0.07$ & $15.61 \pm 0.69$ & $1.86 \pm 0.19$ & $1.26 \pm 0.21$ & $10.06 \pm 0.95$ \\
\hline $\operatorname{TFC}\left(2.5 \mathrm{t} \mathrm{ha}^{-1}\right)$ & $2.44 \pm 0.11$ & $1.60 \pm 0.10$ & $14.60 \pm 0.87$ & $1.62 \pm 0.20$ & $1.35 \pm 0.23$ & $10.51 \pm 0.87$ \\
\hline $\operatorname{TFC}\left(5 \mathrm{tha}^{-1}\right)$ & $2.43 \pm 0.09$ & $1.73 \pm 0.17$ & $16.13 \pm 1.23$ & $1.67 \pm 0.32$ & $1.25 \pm 0.17$ & $10.04 \pm 1.75$ \\
\hline Phosphogypsum & $2.66 \pm 0.17$ & $1.28 \pm 0.12$ & $16.06 \pm 0.98$ & $1.92 \pm 0.28$ & $1.25 \pm 0.31$ & $10.42 \pm 1.64$ \\
\hline Desaline & $2.80 \pm 0.14$ & $1.6 \pm 0.05$ & $16.31 \pm 1.18$ & $1.93 \pm 0.14$ & $1.27 \pm 0.27$ & $10.59 \pm 2.01$ \\
\hline Humic acid & $2.71 \pm 0.20$ & $1.6 \pm 0.11$ & $15.85 \pm 0.88$ & $1.88 \pm 0.25$ & $1.15 \pm 0.16$ & $10.28 \pm 1.65$ \\
\hline Significance & ** & ** & * & ** & ** & * \\
\hline $\mathrm{LSD}_{0.05}$ & 0.15 & 0.16 & 0.71 & 0.14 & 0.09 & 0.13 \\
\hline
\end{tabular}

\section{Application of treated filter cake and molasses enhances soil chemical properties}

The application of treated filter cake and molasses as soil amendments significantly affected the soluble anions and cations and the available N, P and K in the soil. The highest values of the soil available N, P and K in the soil after sugar beet harvest (38.10, 14.21 and $482.63 \mathrm{ppm}$ ) resulted from the application of 5 ton ha $^{-1}$ of treated filter cake (Table 3). Furthermore, the application of 5 ton ha ${ }^{-1}$ of treated filter cake drastically increased the average content of $\mathrm{Ca}^{2+}, \mathrm{Mg}^{+}, \mathrm{K}^{+}, \mathrm{HCO}_{3}{ }^{2-}$ and $\mathrm{SO}^{-}{ }_{4}$ in the soil. Meanwhile, the average content of either $\mathrm{Na}^{+}$and $\mathrm{Cl}^{-}$in the soil as well as the EC and SAR levels of the soil were drastically reduced compared to the control treatment (Table 3). 
Table 3

Effect of soil amendments application on soluble cations and anions and the available $\mathrm{N}, \mathrm{P}$ and $\mathrm{K}$ at the experimental soil after sugar beet harvest over the 2017/2018 and 2018/2019 growing seasons.

\begin{tabular}{|c|c|c|c|c|c|c|c|c|c|c|c|c|}
\hline \multirow[t]{2}{*}{ Treatment } & \multicolumn{4}{|c|}{ Cation (meq L-1) } & \multicolumn{3}{|c|}{ Anions (meq $\mathrm{L}^{-1}$ ) } & \multicolumn{3}{|c|}{$\begin{array}{l}\text { Available nutrients } \\
\text { (ppm) }\end{array}$} & \multirow{2}{*}{$\begin{array}{l}\mathrm{EC} \\
(\mathrm{dS} \\
\mathrm{m}^{-} \\
\left.{ }^{1}\right)\end{array}$} & \multirow[t]{2}{*}{ SAR } \\
\hline & $\mathrm{Ca}^{2+}$ & $\mathrm{Mg}^{2+}$ & $\mathrm{Na}^{+}$ & $\mathrm{K}^{+}$ & $\mathrm{Cl}^{-}$ & $\mathrm{HCO}_{3}^{-}$ & $\mathrm{SO}_{4}{ }^{2-}$ & $\mathbf{N}$ & $\mathbf{P}$ & $\mathrm{K}$ & & \\
\hline Control & 21.96 & 11.97 & 44.37 & 1.18 & 46.23 & 5.11 & 31.22 & 30.85 & 4.31 & 412.19 & 8.57 & 10.77 \\
\hline $\begin{array}{l}\text { Molasses }(62.5 \\
\left.\mathrm{L} \mathrm{ha}^{-1}\right)\end{array}$ & 31.89 & 14.21 & 31.21 & 1.22 & 34.52 & 6.23 & 39.55 & 34.23 & 8.12 & 442.28 & 6.41 & 6.50 \\
\hline $\begin{array}{l}\text { Molasses }(125 \mathrm{~L} \\
\left.\mathrm{ha}^{-1}\right)\end{array}$ & 32.06 & 15.22 & 30.22 & 1.29 & 34.79 & 6.09 & 39.11 & 35.63 & 10.52 & 433.10 & 6.09 & 6.22 \\
\hline $\operatorname{TFC}\left(2.5 \mathrm{t} \mathrm{ha}^{-1}\right)$ & 36.34 & 15.09 & 24.65 & 1.39 & 28.33 & 7.24 & 42.32 & 36.55 & 9.57 & 475.33 & 4.21 & 4.86 \\
\hline $\operatorname{TFC}\left(5 \mathrm{tha}^{-1}\right)$ & 44.37 & 17.02 & 14.82 & 1.62 & 21.64 & 10.38 & 45.99 & 38.10 & 14.21 & 482.63 & 2.43 & 2.67 \\
\hline Phosphogypsum & 35.11 & 15.33 & 21.58 & 1.33 & 29.35 & 4.59 & 42.01 & 29.35 & 11.87 & 448.50 & 4.05 & 4.30 \\
\hline Desal & 27.58 & 12.98 & 37.11 & 1.24 & 40.12 & 4.72 & 35.63 & 28.64 & 7.46 & 428.79 & 6.94 & 8.24 \\
\hline Humic acid & 27.14 & 13.54 & 39.23 & 1.23 & 40.88 & 4.89 & 34.82 & 32.20 & 6.55 & 405.77 & 7.39 & 8.70 \\
\hline Significance & ** & ** & ** & ** & ** & ** & ** & ** & ** & ** & ** & ** \\
\hline $\operatorname{LSD}_{0.05}$ & 1.08 & 0.57 & 2.59 & 0.14 & 4.35 & 1.61 & 2.07 & 1.29 & 2.19 & 5.61 & 1.87 & 2.76 \\
\hline
\end{tabular}

\section{Juice Beet juice quality and sugar loss correlations to the application of soil amendments}

The regression analysis between either $\mathrm{Na}^{+}$content in the soil that was drastically reduced in response to the application of soil amendments, in particular the treated filter cake, and between the soil $\mathrm{Ca}^{2+}$ and $\mathrm{K}$ contents that have significantly improved by the application of treated filter cake, quality index (Qz\%), sugar loss (SL\%), sugar loss yield and relative sugar loss yield over the two growing seasons fitted to the linear equation (Fig. 2). The linear regression model revealed that the soil $\mathrm{Na}^{+}$content is negatively correlated with quality index and sugar loss yield with coefficients of determination $\left(R^{2}\right)$ of 0.513 and 0.219 , respectively. Meanwhile, sugar loss percentage and relative sugar loss yield revealed positive correlations with the soil $\mathrm{Na}^{+}$content with coefficients of determination $\left(R^{2}\right)$ of 0.492 and 0.662 , respectively (Fig. 2). Quality index and sugar loss yield were significantly reduced in response to increasing soil $\mathrm{Na}^{+}$content. Meanwhile, increasing $\mathrm{Na}^{+}$content in the soil significantly increased the sugar loss percentage and relative sugar loss yield. The available soil K content exhibited positive linear regressions with quality index, sugar loss yield and relative sugar loss yield with coefficients of determination $\left(R^{2}\right)$ of $0.642,0.176$ and 0.586 , respectively, and a negative linear regression with sugar loss percentage with an $\mathrm{R}^{2}$ value of 0.717 (Fig. 2). The soluble $\mathrm{Ca}^{2+}$ content in the soil revealed significant positive regression with quality index and sugar loss yield, with $R^{2}$ values of 0.473 and 0.183 , respectively. Meanwhile, the correlations between soil $\mathrm{Ca}^{2+}$ content and either sugar loss percentage or relative sugar loss yield was negative with $R^{2}$ values of 0.467 and 0.589 , respectively (Fig. 3). In addition, quality index and sugar loss yield were increased in response to increasing the $\mathrm{Ca}^{2+}$ in the soil, whereas the sugar loss percentage and relative sugar loss yield were reduced as the soil $\mathrm{Ca}^{2+}$ content was increased.

\section{Discussion}

(Kaffka \&Hembree 2004, Kaffka et al. 2005, Lv et al. 2019)Several effective and low-cost soil amendment approaches have been used worldwide for the remediation of soil salinity through the application of chemical agents including; i) calcium compounds, ii) 
sulfur compounds, and iii) organic matter (Cha-um \&Kirdmanee 2011, Ding et al. 2020, Jesus et al. 2015). Sugar beet industrial byproducts including filter cake are annually produced in huge quantities from beet sugar factories worldwide causing environmental problems. Filter cake, the filtrate residue of the sugar beet juice treatment, is a rich source of organic matter and phosphorus and has a large moisture content with a relatively high CEC value has been widely implemented for complete or partial substitution of mineral fertilizers in crop plants including sugar beet (Prado et al. 2013). Thus, efficient utilization of the very large quantities of the annually produced filter cake is a great challenge.

In the current study, we report, for the first time to the best of our knowledge, the impacts of the application of filter cake treated with a mixture of sulfuric and phosphoric acids on juice quality of sugar beet root and sugar losses into molasses during beet sugar processing under saline soil conditions. The application of soil amendments did not enhance sucrose content in the beet roots and the highest sucrose content produced from the control treatment. This could be resulted from the high calcium content of the applied soil amendments which is antagonized with sodium ions and improves soil aggregation and hence improves the chemical and physical soil characteristics and ultimately enhances plant growth and yield (Miller \&Smith 2010). Moreover, the high sucrose content resulted from the control treatment might be due to that the partitioning of photoassimilates was in favor of increasing sucrose content in the control treatment where root yield was decreased (Hosseini et al. 2019, Koch et al. 2019, Lemoine et al. 2013, Sowiński 1999). In addition, sucrose content has been reported to be reduced in response to increasing beet root yield by the dilution effect (Shaheen et al. 2017).

The significant reduction in $\mathrm{K}, \mathrm{Na}$ and a-amino-N contents in the beet root juice in response to the application of treated filter cake (either 2.5 or 5 ton ha-1 ) could be due to that the excessive concentration of $\mathrm{Ca}^{2+}$ ions led to a reduction in the absorption of $\mathrm{Na}^{+}$ and $\mathrm{K}^{+}$and therefore affected membrane permeability to control $\mathrm{Na}$ absorption (Wakeel 2013). This action of $\mathrm{Ca}^{2+}$ in antagonizing the absorption of $\mathrm{Na}^{+}$and $\mathrm{K}^{+}$ions from the soil is supported by the linear regression relationships between $\mathrm{Ca}^{2+}$ and both $\mathrm{Na}$ and $\mathrm{K}$ content in the beet roots. The contents of either $\mathrm{Na}$ or $\mathrm{K}$ in the beet roots were significantly reduced in response to increasing $\mathrm{Ca}^{2+}$ content in the soil (Fig. 3). Moreover, soil amendments, depending on the type of elements and amendments, could promote contradictory impacts on the mobilization and phytoavailability of the elements (Shaheen et al. 2017).

The significant reduction in sugar loss percentage in response to the application of treated filter cake could be due to the reduction in $\mathrm{Na}^{+}$content as a result of increasing $\mathrm{Ca}^{2+}, \mathrm{HCO}^{2-}{ }_{3}$ and $\mathrm{SO}_{4}^{-}$contents in the soil (Table 3) which influence the uptake of $\mathrm{Na}^{+}$and $\mathrm{K}^{+}$by the plants. This reduction in the absorption of $\mathrm{Na}^{+}$and $\mathrm{K}^{+}$leads to a reduction in the $\mathrm{Na}$ and $\mathrm{K}$ contents in the beet root juice which consequently reduces sucrose losses into molasses during beet sugar processing. This notion is supported by the linear regression relationships between the soil $\mathrm{Na}^{+}$and $\mathrm{Ca}^{+}$contents and the $\mathrm{Na}$ content in the beet juice. The root $\mathrm{Na}$ content was reduced in response to the reduction in the $\mathrm{Na}^{+}$soil content caused by the application of soil amendments, in particular treated filter cake. Moreover, increasing $\mathrm{Ca}^{+}$content in the soil in response to the application of filter cake, which is due to the high contents of both elements in the filter cake, is correlated with a reduction in the $\mathrm{Na}$ in the beet root (Fig. 4). The high sugar loss yield resulted from the application of treated filter cake could be due to the high root yield achieved from the application of this treatment (Table 4). Additionally, the high concentration of $\mathrm{Ca}$ in the treated filter cake reduces both $\mathrm{Na}$ and $\mathrm{K}$ immobilization and bioavailability through reducing the soil $\mathrm{pH}$ and antagonistic improvement of the availability of exchangeable Ca in the soil (Bhuiyan et al. 2015, David 2007, Hasanuzzaman et al. 2014). However, the relative loss in sugar yield was reduced in response to the application of treated filter cake, and this is probably due to the reduction in the impurities, i.e., $\mathrm{Na}$, $\mathrm{K}$ and aamino $\mathrm{N}$ contents in the beet root caused by the application of treated filter cake. Furthermore, positive linear regressions were observed between either $\mathrm{Na}$ and $\mathrm{K}$ contents in the soil and the reduction in relative sugar loss yield (Fig. 2). 
Table 4

Effect of soil amendments application on root (RY) and recoverable sugar yields (RSY) of sugar beet in the $2017 / 2018$ and $2018 / 2019$ growing seasons.

\begin{tabular}{|c|c|c|c|c|}
\hline & $2017 / 2018$ & & $2018 / 2019$ & \\
\hline Treatment & $\mathrm{RY}\left(\mathrm{t} \mathrm{ha}^{-1}\right)$ & $\mathrm{RSY}\left(\mathrm{t} \mathrm{ha}^{-1}\right)$ & $\mathrm{RY}\left(\mathrm{t} \mathrm{ha} \mathrm{C}^{-1}\right)$ & $\mathrm{RSY}\left(\mathrm{t} \mathrm{ha} \mathrm{-}^{-1}\right)$ \\
\hline Control & $48.2 \pm 4.09$ & $7.18 \pm 1.22$ & $57.15 \pm 5.47$ & $9.42 \pm 0.76$ \\
\hline Molasses (62.5 L ha-1) & $56.85 \pm 3.78$ & $8.23 \pm 1.01$ & $63.7 \pm 4.36$ & $10.33 \pm 0.78$ \\
\hline Molasses (125 L ha-1) & $57.13 \pm 5.11$ & $8.30 \pm 0.93$ & $66.09 \pm 4.37$ & $10.78 \pm 0.83$ \\
\hline $\operatorname{TFC}\left(2.5 \mathrm{tha}^{-1}\right)$ & $65.28 \pm 3.44$ & $9.33 \pm 0.84$ & $73.66 \pm 5.08$ & $11.5 \pm 0.94$ \\
\hline $\operatorname{TFC}\left(5 \mathrm{t} \mathrm{ha}^{-1}\right)$ & $63.33 \pm 4.56$ & $9.00 \pm 0.79$ & $68.03 \pm 4.22$ & $10.93 \pm 1.08$ \\
\hline Phosphogypsum & $47.98 \pm 6.22$ & $6.68 \pm 1.13$ & $62.57 \pm 3.98$ & $10.41 \pm 1.23$ \\
\hline Desal & $57.2 \pm 5.32$ & $8.23 \pm 0.65$ & $65.88 \pm 2.94$ & $10.73 \pm 0.81$ \\
\hline Humic acid & $58.9 \pm 3.97$ & $8.47 \pm 0.99$ & $61.00 \pm 2.37$ & $10.00 \pm 1.11$ \\
\hline Significance & ** & ** & ** & ** \\
\hline $\operatorname{LSD}_{0.05}$ & 1.23 & 0.18 & 2.89 & 0.13 \\
\hline
\end{tabular}

In conclusion, the current study provides the beet sugar processing byproduct filter cake treated with a mixture of sulfuric and phosphoric acids as a powerful and cost-effective soil amendment with a great potential for sustainable production of crop plants in saline soils for conservation agriculture. Treated filter cake is a promising organic soil amendment that could greatly improve the physical and chemical properties of the soil, organize nutrients and elements uptake, and ultimately impact the quality and biofortification of crop plants.

\section{Declarations}

\section{Ethics approval and consent to participate}

Not applicable.

\section{Consent to Participate}

Not applicable.

\section{Funding}

Not applicable.

\section{Authors' contributions}

SFA conceived the study, analyzed the data, and wrote the manuscript. FMI performed the experiment and collected the data. FA, $A A B$ and WZ helped in data analysis and presentation. All authors read and approved the final version of the manuscript. 
All data are included within the manuscript and its supplementary material.

\section{Competing interests}

The authors declare that there is no conflict of interest.

\section{Acknowledgments}

The authors gratefully acknowledge the staff of the Delta Sugar Company Research Farm, Kafr El-Sheikh, Egypt for excellent technical assistance.

\section{References}

Abejehu G (2015): Effect of filter cake and nitrogen fertilizer (Urea) on yield of sugarcane at Wonji-Shoa Sugar Estate Scholarly. Journal of Agricultural Science 5

Abo-Elwafa SF, Abdel-Rahim HM, Abou-Salama AM, Teama EA (2006): Sugar beet floral induction and fertility: effect of vernalization and day-length extension. Sugar Tech 8, 281-287

Abo-Elwafa SF, Abdel-Rahim HM, Abou-Salama AM, Teama E-MA (2013): Effect of Root Age and Day-Length Extension on Sugar Beet Floral Induction and Fertility. World Journal of Agricultural Research 1

Abou-Elwafa SF, Amin AE-EA, Eujayl I (2020): Genetic diversity of sugar beet under heat stress and deficit irrigation. Agronomy Journal

Ahmed KG, Qadir AR, Jami MQ, Nawaz A, Rehim A, Jabran K, Hussain M (2015): Gypsum and farm manure application with chiseling improve soil properties and performance of fodder beet under saline-sodic conditions. International Journal of Agriculture and Biology 17

Balakrishnan A, Selvakumar T (2009): Evaluation of suitable tropical sugarbeet hybrids with optimum time of sowing. Sugar Tech $11,65-68$

Basha AAAB (2011): Improving filter mud cake with rock phosphate and biofertilizers for exporting organic onion production in newly cultivated land at South Valley area. Australian Journal of Basic and Applied Sciences 5, 1354-1361

Bhuiyan MSI, Raman A, Hodgkins DS, Mitchell D, Nicol HI (2015): Salt Accumulation and Physiology of Naturally Occurring Grasses in Saline Soils in Australia. Pedosphere 25, 501-511

Burt R 2004: Soil survey laboratory methods manual. Soil Survey Investigations Report No. 42, United States Department of Agriculture, Natural Resources Conservation Service, National Soil Survey Center, USA

Cha-um S, Kirdmanee C (2011): Remediation of salt-affected soil by the addition of organic matter: an investigation into improving glutinous rice productivity. Scientia Agricola 68, 406-410

Dadkhah AR (2008): Response of root yield and quality of sugar beet (Beta vulgaris) to salt stress

David F 2007: Salt Accumulation Processes, North Dakota state University, Fargo ND

Ding Z, Kheir AMS, Ali MGM, Ali OAM, Abdelaal AIN, Lin Xe, Zhou Z, Wang B, Liu B, He Z (2020): The integrated effect of salinity, organic amendments, phosphorus fertilizers, and deficit irrigation on soil properties, phosphorus fractionation and wheat productivity. Scientific Reports 10, 2736

Draycott AP, Christenson DR (2003): Nutrients for Sugar Beet Production. CAB International, UK, 272 pp

El-Hassanin AS, Moustafa MRS, Shafika N, Khalifa AM, Inas MI (2016): Effect of Foliar Application with Humic Acid Substances under Nitrogen Fertilization Levels on Quality and Yields of Sugar Beet Plant. International Journal of Current Microbiology and

Page $10 / 16$ 
Applied Sciences 5

El-Tokhy FK, Tantawy AS, El-Shinawy MZ, Hadid AFA-E- (2019): Effect of sugar beetmolass and Fe-EDHHA on tomato plants grown under saline water irrigation condition Arab Univiversity Journal of Agricultural Science 26

Hasanuzzaman M, Alam MM, Rahman A, Hasanuzzaman M, Nahar K, Fujita M (2014): Exogenous Proline and Glycine Betaine Mediated Upregulation of Antioxidant Defense and Glyoxalase Systems Provides Better Protection against Salt-Induced Oxidative Stress in Two Rice (<i>Oryza sativa</i> L.) Varieties. BioMed Research International 2014, 757219

Hesse PR (1998): A textbook of soil chemical analysis. CBS Publishers \& Distributors, Delhi, India

Hosseini SA, Réthoré E, Pluchon S, Ali N, Billiot B, Yvin JC (2019): Calcium Application Enhances Drought Stress Tolerance in Sugar Beet and Promotes Plant Biomass and Beetroot Sucrose Concentration. Int J Mol Sci 20

Ippolito JA, Strawn DG, Scheckel KG (2013): Investigation of copper sorption by sugar beet processing lime waste. J Environ Qual $42,919-24$

Jackson ML (1973): Soil chemical analysis. In: Englewood Cliffs N (Editor). Prentice-Hall, Inc., New Delhi, India

Jesus JM, Danko AS, Fiúza A, Borges M-T (2015): Phytoremediation of salt-affected soils: a review of processes, applicability, and the impact of climate change. Environmental Science and Pollution Research 22, 6511-6525

Kaffka S, Hembree K (2004): The Effects of Saline Soil, Irrigation, and Seed Treatments on Sugarbeet Stand Establishment. Journal of Sugar Beet Research 41

Kaffka SR, Lesch SM, Bali KM, Corwin DL (2005): Site-specific management in salt-affected sugar beet fields using electromagnetic induction. Computers and Electronics in Agriculture 46, 329-350

Koch M, Busse M, Naumann M, Jákli B, Smit I, Cakmak I, Hermans C, Pawelzik E (2019): Differential effects of varied potassium and magnesium nutrition on production and partitioning of photoassimilates in potato plants. Physiologia Plantarum 166, 921935

Le-Docte A (1927): Commercial determination of sugar in the beet root using the sacks. Process. Int. Sug. J. 29, 5

Lemoine R, La Camera S, Atanassova R, Dédaldéchamp F, Allario T, Pourtau N, Bonnemain J-L, Laloi M, Coutos-Thévenot P, Maurousset L, Faucher M, Girousse C, Lemonnier P, Parrilla J, Durand M (2013): Source-to-sink transport of sugar and regulation by environmental factors. Frontiers in Plant Science 4

Lv X, Chen S, Wang Y (2019): Advances in Understanding the Physiological and Molecular Responses of Sugar Beet to Salt Stress. Frontiers in Plant Science 10

Messiha NAS, van Bruggen AHC, van Diepeningen AD, de Vos OJ, Termorshuizen AJ, Tjou-Tam-Sin NNA, Janse JD (2007): Potato brown rot incidence and severity under different management and amendment regimes in different soil types. European Journal of Plant Pathology 119, 367-381

Miller DJ, Smith GL (2010): Lüttgau \& Niedergerke; the classic study of calcium-sodium antagonism half a century on. The Journal of Physiology 588, 23-25

Olsen SR (1954): Estimation of available phosphorus in soils by extraction with sodium bicarbonate.

Ossom EM, Rhykerd RL (2007): Response of Ipomoea batatas (L.) Lam. to soil fertilization with filter cake. Transactions of the Illinois State Academy of Science 100

Ossom EM, Dlamini FT (2012): Effects of filter cake on soil mineral nutrients and maize (Zea mays L.) agronomy. Tropical Agriculture 80

Page $11 / 16$ 
Ossom EM (2010): Effects of filter cake fertilization on weed infestation, disease incidence and tuber yield of Cassava (Manihot esculenta) in Swaziland. International Journal of Agriculture and Biology (Pakistan) v. 12

Prado RdM, Caione G, Campos CNS (2013): Filter Cake and Vinasse as Fertilizers Contributing to Conservation Agriculture. Applied and Environmental Soil Science 2013, 581984

Reinefield E, Merich AEM, Baumgarten G, Winner C, Besis U (1974): Zur Voraussage des melassezyu cherus aus Ru beanalysen. In: Cooke DA , Scott RK (Editors), The Sugar beet Crop. Chapman and Hall (World Crop Series), London, U.K. , pp. 571-617

Shaheen SM, Shams MS, Khalifa MR, El-Dali MA, Rinklebe J (2017): Various soil amendments and environmental wastes affect the (im)mobilization and phytoavailability of potentially toxic elements in a sewage effluent irrigated sandy soil. Ecotoxicology and Environmental Safety 142, 375-387

Sowiński P (1999): Transport of photoassimilates in plants under unfavourable environmental conditions. Acta Physiologiae Plantarum 21, 75

Tan KH (2003): Humic Matter in Soil and Environment, Principles and Controversies. CRC Press, Madison, New York, 495 pp

Wakeel A (2013): Potassium-sodium interactions in soil and plant under saline-sodic conditions. Journal of Plant Nutrition and Soil Science 176, 344-354

Wu L, Feng G, Letey J, Ferguson L, Mitchell J, McCullough-Sanden B, Markegard G (2003): Soil management effects on the nonlimiting water range. Geoderma 114, 401-414

\section{Figures}



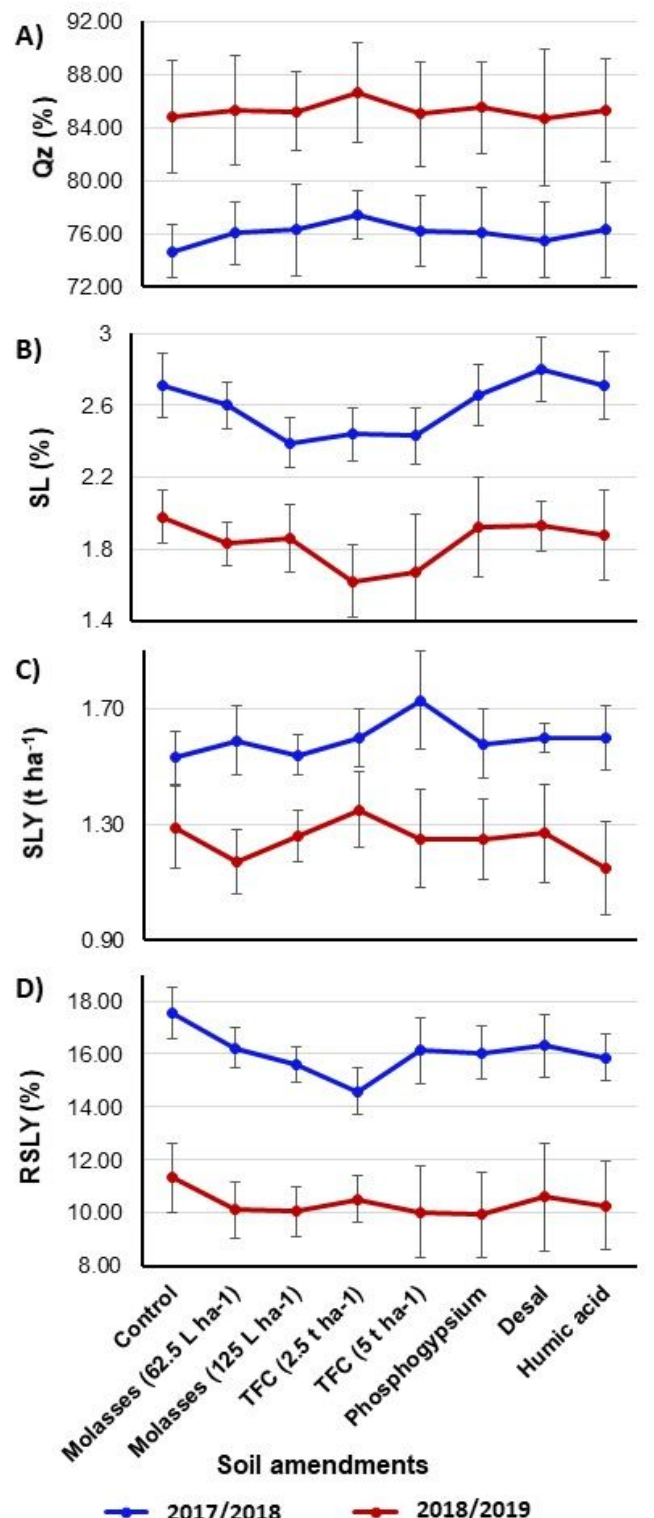

\section{Figure 1}

Response of quality and sugar losses of sugar beet grown in saline soils to the application of soil amendments. QZ; Quality index, SL; Sugar losses, SLY; Sugar loss yield, RSLY; Relative sugar loss yield. 

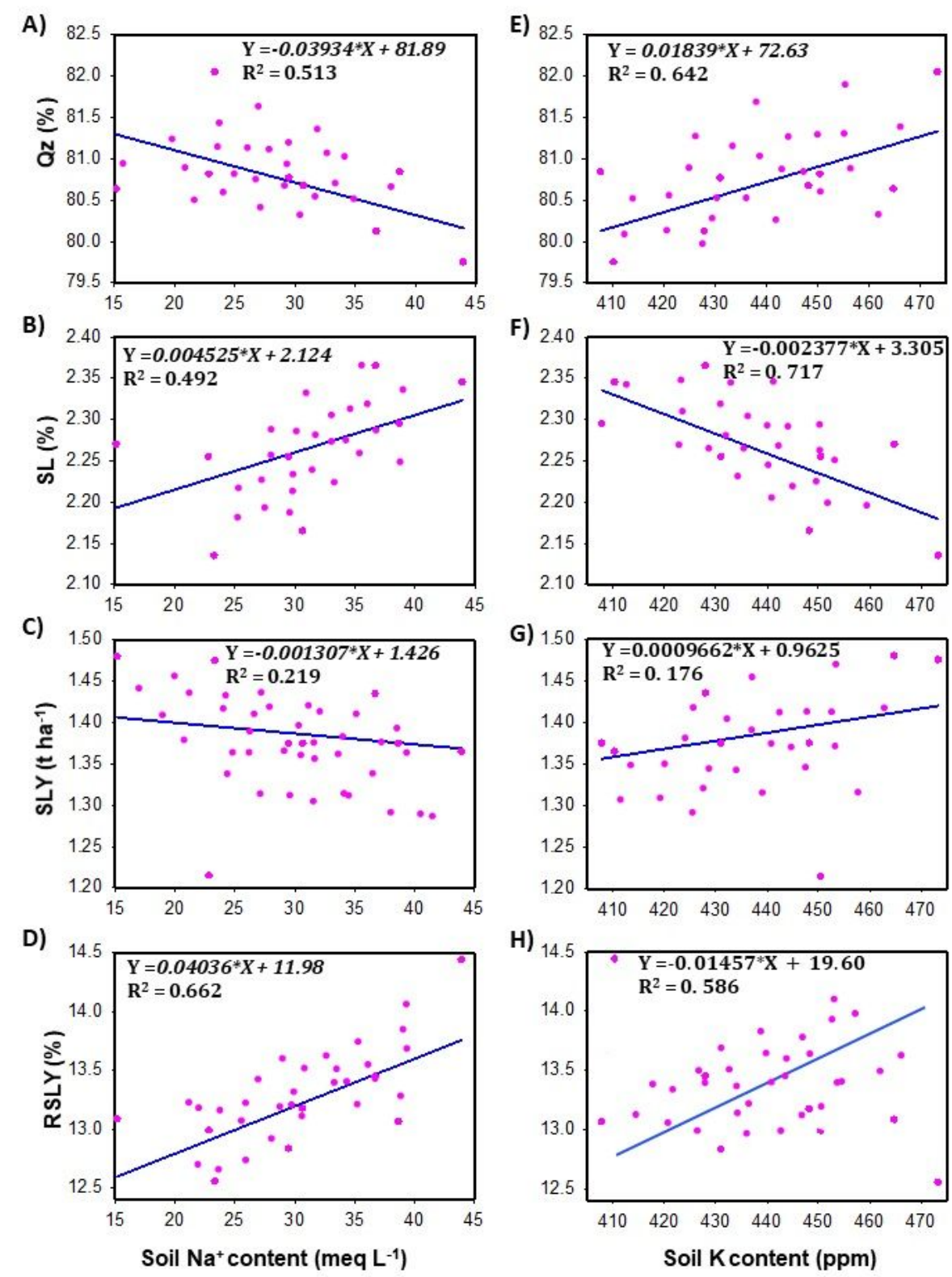

\section{Figure 2}

Regression analysis between quality index (Qz), sugar losses (SL), sugar loss yield (SLY) and relative sugar loss yield (RSLY), and soil $\mathrm{Na}+$ and K contents fitted by the linear-linear model over the two growing seasons 2017/2018 and 2018/2019. 

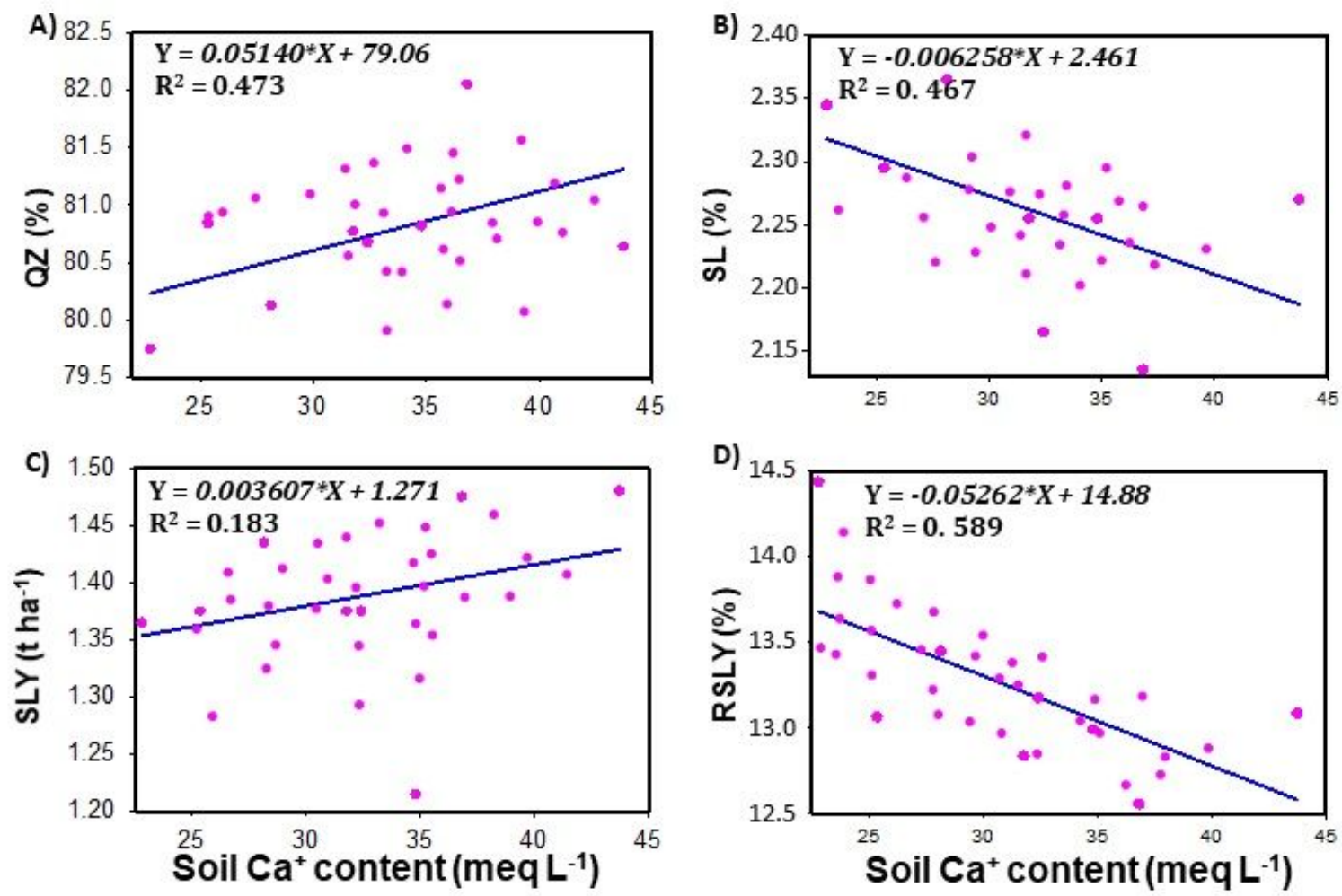

Figure 3

Response of quality index (Qz), sugar losses (SL), sugar loss yield (SLY) and relative sugar loss yield (RSLY) to soil Ca2+ content fitted by the linear-linear model over the 2017/2018 and 2018/2019 growing seasons.
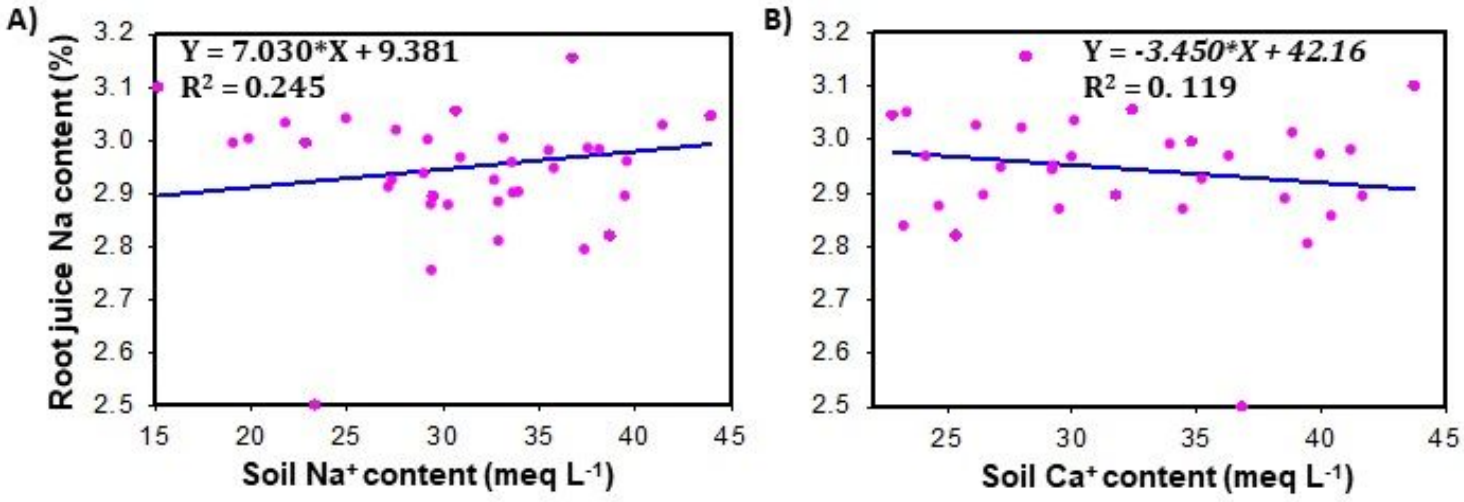

\section{Figure 4}

Response of $\mathrm{Na}$ in the beet root juice to soil $\mathrm{Na}+$ and $\mathrm{Ca} 2+$ contents fitted by the linear-linear model over the 2017/2018 and $2018 / 2019$ growing seasons.

\section{Supplementary Files}


This is a list of supplementary files associated with this preprint. Click to download.

- Suppl.Table1.docx

- Suppl.Table2.docx

- Suppl.Table3.docx

- Suppl.Table4.docx

- Suppl.Table5.docx 